\title{
Occupational exposure to ionising radiation and mortality among workers of the former Spanish Nuclear Energy Board
}

Fernando Rodríguez Artalejo, Santiago Castaño Lara, Belén de Andrés Manzano, Margarita García Ferruelo, Luis Iglesias Martín, Juan del Rey Calero

\begin{abstract}
Objectives-Firstly, to ascertain whether mortality among workers of the former Spanish Nuclear Energy Board Uunta de Energia Nuclear-JEN) was higher than that for the Spanish population overall; and secondly, if this were so, to ascertain whether this difference was associated with exposure to ionising radiation.

Methods-A retrospective follow up of a cohort of 5657 workers was carried out for the period 1954-92. Cohort mortality was compared with that for the Spanish population overall, with standardised mortality ratios (SMRs) adjusted for sex, age, and calendar period. Also, Poisson models were used to analyse mortality from lung cancer in the cohort by level of exposure to ionising radiation.
\end{abstract}

Results-Workers' median and mean cumulative exposures were 4.04 and 11.42 mSv, respectively. Mean annual exposure was $1.33 \mathrm{mSv}$. Excess mortality due to bone tumours was found for the cohort as a whole (six deaths observed; SMR 2.95; $95 \%$ confidence interval (95\% CI) 1.08 to 6.43). Among miners, excess mortality was found for non-malignant respiratory diseases (SMR 2.94; 95\% CI 2.27 to 3.75), and for lung cancer bordering on statistical significance (SMR 1.50; 95\% CI 0.96 to $2 \cdot 23 ; \mathbf{P}=0.055)$. Relative risks of dying of lung cancer from ionising radiation in the dose quartiles 2,3 , and 4 versus the lowest dose quartile, were $1.00,1.64$, and 0.94 , respectively.

Conclusions-Excess mortality from lung cancer was found among JEN miners. Nevertheless, no clear relation was found between mortality from lung cancer and level of exposure to ionising radiation in the JEN cohort. Continued follow up of the cohort is required to confirm excess mortality from bone tumours.

(Occup Environ Med 1997;54:202-208)

Keywords: ionising radiation; lung cancer; epidemiological study; retrospective cohort

High doses of ionising radiation increase the risk of developing different types of cancer, and leukaemias in particular (except chronic lymphoid leukaemia). Current radiological protection standards are based on estimates, extrapolated from high dose risks, of the risk likely to be faced at low doses commonly encountered in the workplace..$^{13}$ However, such estimates are subject to uncertainties stemming from the type of assumptions made in the extrapolation. Thus, the only direct way of ascertaining what really occurs at low doses is to study large populations similarly exposed..$^{45}$

The cohort from the now defunct Nuclear Energy Board (Funta de Energia NuclearJEN) is possibly the first and most numerous nationwide occupational cohort followed up in Spain and, to date, has constituted the sole source of information on the possible effects of chronic exposure to low doses of ionising radiation among the Spanish labour force. This paper presents the results of follow up of the cohort for the period 1954-92, and sought to accomplish two objectives: firstly, to ascertain whether work at JEN facilities posed a higher risk of mortality than that faced by the Spanish population as a whole; and secondly, if any such evidence was found, to ascertain whether this difference was associated with exposure to ionising radiation.

Materials and methods

FEATURES OF THE STUDY SITE

The JEN, known nowadays as the Centre for Energy, Environmental, and Technological Studies (Centro de Investigaciones Energéticas, Medioambientales y Tecnológicas-CIEMAT), was set up in 1951 to be the public authority with responsibility at a national level for management and coordination of nuclear activities. From an occupational health standpoint, the most relevant activities undertaken by the JEN over the past 45 years have been research and teaching in the nuclear field, prospecting and exploitation of radioactive minerals in over 26 mines throughout Spain, and authorisation and inspection of nuclear and radioactive facilities. At present, the JEN runs just one centre, situated on the campus of the Universidad Complutense de Madrid, and some of its former staff have been transferred to the Consejo de Seguridad Nuclear (Nuclear Security Board), Empresa Nacional de UranioNational Uranium Corporation (ENUSA), and Empresa Nacional de Residuos RadiactivosNational Radioactive Waste Corporation (ENRESA). Moreover, its activities are no longer confined to nuclear energy and include research into energy of all types and their environmental impact.

STUDY POPULATION

A retrospective follow up was carried out on a cohort of $5657 \mathrm{JEN}$ workers (4711 men and 
946 women), who had been in the Board's direct employment for over six months between 1 January 1954 and 31 December 1992.

Of the 7002 permanent workers at JEN during the course of its corporate existence, a total of $1345(19 \cdot 25 \%)$ were excluded from the analysis for three different reasons: 272 $(3.88 \%)$ for lacking sufficient identification and work related data to conduct a follow up and assess their mortality; $31(0.44 \%)$ for having served out their entire term of employment before the date the follow up started; and 1042 $(14 \cdot 88 \%)$ for having been employed for less than six months.

Follow up of each worker began six months after the date of hire at JEN and ended at the time of death, 31 December 1992, or the date of last contact if before 31 December 1992.

\section{DATA GATHERING}

The following information was gathered for each subject in the study population.

\section{Administrative and clinical data}

The primary source of information was the records of the CIEMAT's Personnel and Organisation Department; other sources of data used were medical records belonging to the Occupational Health Unit, and dosimetric records kept by the Personnel Dosimetry Section. Information used for each worker covered affiliation, date, smoking, and age at the start and end of the period worked at JEN in all capacities and in its mining operations.

\section{Exposure data (dosimetry)}

All information was gathered from the dosimetric records kept by the CIEMAT's Personnel Dosimetry Section. The information used for each worker covered date and age at first and last exposure to ionising radiation, and cumulative year by year body dose from 1954 to 1992 .

Dosimetric data related to doses (expressed in units of effective dose (mSv)) of external penetrating radiation, estimated through personal body dosimetry. Although some readings of internal contamination had been taken for the period in question, they were operational controls not designed as individual dosimetric monitoring and thus were not usable. Similarly, doses due to radon inhalation and other natural sources were not taken into account, owing to the paucity and poor reliability of environmental measurements performed.

Doses were measured with film dosimeters, Dupont film was used for the period 1954-70 and Kodak film thereafter. For most of the follow up period and most of the workers, dosimeters were issued monthly. Frequency of missing measurements was very low, and zero dose was recorded when a measurement was missing. Finally, detection thresholds have been estimated to be $0 \cdot 1-0.2 \mathrm{mSv}$, and recording threshold $0.2 \mathrm{mSv}$.

Data on total and cause specific mortality Information was gathered on the vital status of all workers in the study population, including date of death and cause where applicable. For follow up purposes, the following criteria and methods were used.

(1) All those workers who, on 31 December 1992, were actively employed at the CIEMAT or (if transferred) at the Nuclear Security Board, ENRESA and ENUSA, were deemed to be alive.

(2) In the case of workers who had died during active service with any of the four organisations, date and cause of death were found through the respective Personnel and Medical Service Departments.

(3) Vital status, and where applicable, date and cause of death for the remaining workers were found by means of consulting Social Security databases, and civil registries in towns where the main centres of activity had been located, for the period 1 January 1954-31 December 1986. It was also ascertained from the databases on mortality and causes of death kept by the National Statistics Office (Instituto Nacional de Estadistica (INE)), for the period 1 January 1987-31 December 1992.

All registered causes of death were coded to the international classification of diseases 9 th revision (ICD-9). ${ }^{6}$

\section{STATISTICAL ANALYSIS}

External comparison was carried out between mortality among the JEN workers and that of the Spanish population. Standardised mortality ratios (SMRs) adjusted for sex, age, and calendar period, were computed. These were obtained by taking JEN deaths (total and cause specific) and dividing them by the deaths which would be expected if JEN workers conformed to the mortality pattern for the Spanish population overall. ${ }^{78}$ Also, SMRs were calculated on the assumption of five and 10 year latency periods for the potential effects of exposure to ionising radiation. For this purpose, the first five and 10 years of each worker's follow up were excluded. ${ }^{7}$ Lastly, we calculated the significance and $95 \%$ confidence intervals $(95 \% \mathrm{CI})$ of the SMRs. ${ }^{910}$

Internal comparisons of mortality within the JEN population were carried out by level of ionising radiation. We studied the relation between mortality from lung cancer and cumulative dose of ionising radiation, classified into quartiles. Analysis was effected with Poisson models, constructed on data aggregated from follow up of the cohort (personyears). ${ }^{11-13}$ With the aid of these models, it was possible to ascertain the relative risk (rate ratios) of dying of lung cancer for each quartile of dose of ionising radiation as against the quartile with the lowest dose, adjusted for age, calendar time, and smoking. Relative risks were also ascertained under the assumption of five and 10 year latency periods in the potential effects of exposure to ionising radiation; to this end, models were reassessed with five and 10 year lags for exposure of each worker. These calculations thus involved no reduction in sample size. ${ }^{7}$

All analyses were run on the full JEN cohort and three selected subcohorts: one composed 
Table 1 Administrative characteristics, exposure to ionising radiation, and vital status of the study population

\begin{tabular}{|c|c|c|c|c|}
\hline & Cohort & $\begin{array}{l}\text { Subcohort } \\
\text { Madrid }\end{array}$ & $\begin{array}{l}\text { Subcohort } \\
\text { miners }\end{array}$ & $\begin{array}{l}\text { Subcohort } \\
\text { non-miners }\end{array}$ \\
\hline \multicolumn{5}{|l|}{ Administrative characteristics (mean (SD)): } \\
\hline Study population & 5657 & 3135 & 1535 & 4122 \\
\hline Age when hired at JEN (y) & $29 \cdot 4(8 \cdot 9)$ & $27 \cdot 8(8 \cdot 4)$ & $31.9(8 \cdot 6)$ & $28 \cdot 4(8 \cdot 9)$ \\
\hline Duration of employment at JEN & $12 \cdot 6(11 \cdot 3)$ & $13 \cdot 6(11 \cdot 6)$ & $9 \cdot 8(10 \cdot 0)$ & $13.6(11 \cdot 6)$ \\
\hline Duration of employment in mining activities & $5 \cdot 4(5 \cdot 7)$ & & $5 \cdot 5(5 \cdot 7)$ & - \\
\hline \multicolumn{5}{|l|}{ Exposure to ionising radiation: } \\
\hline Population with dosimetric records (n (\%)) & $3398(60 \cdot 1)$ & $2260(72 \cdot 1)$ & $710(46 \cdot 3)$ & $2688(65 \cdot 2)$ \\
\hline Population with dosimetric reading $>0 \mathrm{mSv}(\mathrm{n}(\%))$ & $2940(52 \cdot 0)$ & $1882(60 \cdot 0)$ & $673(43 \cdot 8)$ & $2267(55 \cdot 0)$ \\
\hline Mean (SD) age of first exposure (y) & $32 \cdot 4(9 \cdot 8)$ & $30 \cdot 1(9 \cdot 3)$ & $38 \cdot 0(8 \cdot 7)$ & $30 \cdot 7(9 \cdot 5)$ \\
\hline Mean (SD) time of exposure (y) & $8 \cdot 6(8 \cdot 0)$ & $9 \cdot 2(8 \cdot 3)$ & $5 \cdot 5(5 \cdot 7)$ & $9.5(8.5)$ \\
\hline \multicolumn{5}{|l|}{ Vital status: } \\
\hline Number of deaths in the study population (n (\%)) & $591(10 \cdot 4)$ & $192(6 \cdot 1)$ & $273(17 \cdot 9)$ & $318(7 \cdot 7)$ \\
\hline Mean (SD) follow up (y) & $15 \cdot 9(12 \cdot 3)$ & $15 \cdot 5(12 \cdot 0)$ & $15 \cdot 1(12 \cdot 6)$ & $16 \cdot 2(12 \cdot 1)$ \\
\hline
\end{tabular}

of all workers employed at the Madrid facilities, another composed of all JEN miners, and a third composed of all JEN non-mining staff (non-miners). Statistical analysis was performed with the SAS ${ }^{14}$ and Egret ${ }^{15}$ software packages.

\section{Results}

DESCRIPTION OF THE STUDY POPULATION Administrative characteristics and general description

Of the 5657 subjects studied, $1535(27 \cdot 1 \%)$ had worked in JEN mining operations (table 1). On the whole, this was a population that had been hired in their late 20s (mean (SD) $29.4(8.9)$ ), had first experienced exposure to ionising radiation in the fourth decade of life, and had been employed for slightly over 10 years. There were dosimetric records for 3398 subjects $(60 \cdot 1 \%$ of the cohort), 2940 of whom ( $86.5 \%$ of subjects with dosimetric records) had had doses above the detection threshold.

Mean follow up of the cohort was 15.9 years and mean period of exposure to ionising radiation, 8.6 years. This translated as 89946 person-years of observation and 49216 person-years of exposure to ionising radiation. During follow up, 591 deaths occurred, yielding a cumulative incidence of $10.4 \%$ and 6.6 deaths per 1000 person-years of observation.

The Madrid subcohort had the highest proportion of subjects with dosimetric records $(72 \cdot 1 \%)$, with a cumulative dose of over 0 $\mathrm{mSv}$ in $60.0 \%$ of cases. The miner subcohort showed the lowest percentages in these variables, but had most deaths.

\section{Exposure to ionising radiation}

The collective external dose for JEN staff was $38805 \mathrm{mSv}$, representing a median and mean cumulative dose in subjects with dosimetric records of 4.04 and $11.42 \mathrm{mSv}$, respectively. The mean annual dose was $1.33 \mathrm{mSv}$ (table
2). This dose is roughly equivalent to that received from the natural radioactive background and 38 times lower than the annual permissible limit for professionally exposed workers. ${ }^{16}$

Distribution of exposure was asymmetric (table 2 and figure). Only 937 (27.6\%) workers exceeded a cumulative dose of 10 $\mathrm{mSv}$ and only $46(1.4 \%)$ exceeded $100 \mathrm{mSv}$. Mean cumulative dose increased with duration of employment (figure B), but declined steadily from the earliest years of operation (1954-9) to the present (figure C). The sharpest fall was evident from 1970 onwards. This same phenomenon was found for workers born after 1930 (figure D).

Although doses received by the three subcohorts were similar (table 2 and figure), the miner subcohort registered the highest cumulative dose, and it did not increase with duration of employment when this exceeded 20 years. This finding is due to the fact that from 1970 JEN mining activities were substantially reduced. Doses received by miners remained stable among workers who joined JEN in the period 1954-69.

EXTERNAL COMPARISON BETWEEN MORTALITY AMONG THE JEN POPULATION AND THAT OF THE SPANISH POLULATION

For the cohort as a whole, the SMR for the period 1954-92 for all causes of death was 0.80 (95\% CI 0.74 to 0.87 ) (table 3 ), which means that general mortality among JEN workers was $20 \%$ lower than Spanish mortality nationwide. This was fundamentally due to the low mortality registered by circulatory, infectious, parasitic, and digestive diseases. However, there was a significant excess of deaths induced by non-malignant respiratory diseases. The second leading cause of death in the cohort compared with national mortality proved to be malignant tumours (SMR 0.88 , $95 \%$ CI 0.38 to $1 \cdot 74$ ).

Table 2 Distribution of workers with dosimetric records in categories of cumulative external radiation dose

\begin{tabular}{|c|c|c|c|c|c|c|c|c|c|c|}
\hline & \multicolumn{10}{|l|}{ Dose $(m S v)$} \\
\hline & 0 & -5 & -10 & -20 & -50 & -100 & $>100$ & $\begin{array}{l}\text { Median } \\
\text { dose }\end{array}$ & $\begin{array}{l}\text { Mean } \\
\text { dose }\end{array}$ & $\begin{array}{l}\text { Mean } \\
\text { annual dose }\end{array}$ \\
\hline $\begin{array}{l}\text { Cohort (n (\%)): } \\
\text { Subcohorts }(n(\%)) \text {. }\end{array}$ & $458(13 \cdot 5)$ & $1412(41 \cdot 6)$ & $591(17 \cdot 4)$ & $417(12 \cdot 4)$ & $357(10 \cdot 5)$ & $117(3 \cdot 4)$ & $46(1 \cdot 4)$ & 4.04 & $11 \cdot 42$ & $1 \cdot 33$ \\
\hline $\begin{array}{l}\text { Madrid } \\
\text { Miners (n(\%)) } \\
\text { Non-miners (n (\%)) }\end{array}$ & $\begin{array}{c}378(16 \cdot 7) \\
37(5 \cdot 2) \\
421(15 \cdot 7)\end{array}$ & $\begin{array}{r}950(42 \cdot 0) \\
303(42 \cdot 7) \\
1109(41 \cdot 3)\end{array}$ & $\begin{array}{l}368(16 \cdot 3) \\
147(20 \cdot 7) \\
444(16 \cdot 5)\end{array}$ & $\begin{array}{l}240(10 \cdot 6) \\
106(14.9) \\
311(11.6)\end{array}$ & $\begin{array}{l}185(8 \cdot 2) \\
102(14 \cdot 4) \\
255(9 \cdot 5)\end{array}$ & $\begin{array}{r}97(4 \cdot 3) \\
13(1 \cdot 8) \\
104(3 \cdot 9)\end{array}$ & $\begin{array}{r}42(1 \cdot 9) \\
2(0 \cdot 3) \\
44(1 \cdot 6)\end{array}$ & $\begin{array}{l}3 \cdot 45 \\
5 \cdot 4 \\
3 \cdot 7\end{array}$ & $\begin{array}{l}11 \cdot 75 \\
10 \cdot 74 \\
11 \cdot 61\end{array}$ & $\begin{array}{l}1 \cdot 28 \\
1.95 \\
1 \cdot 22\end{array}$ \\
\hline
\end{tabular}


Cumulative dose of ionising radiation among the $\mathcal{F} E N$ workforce. (A) Distribution of workers by dose. (B) Dose distribution by duration of employment at $\mathcal{F E N}$. (C) Dose distribution by year of hire at $\mathcal{F E N}$. (D) Dose distribution by workers' year of birth.
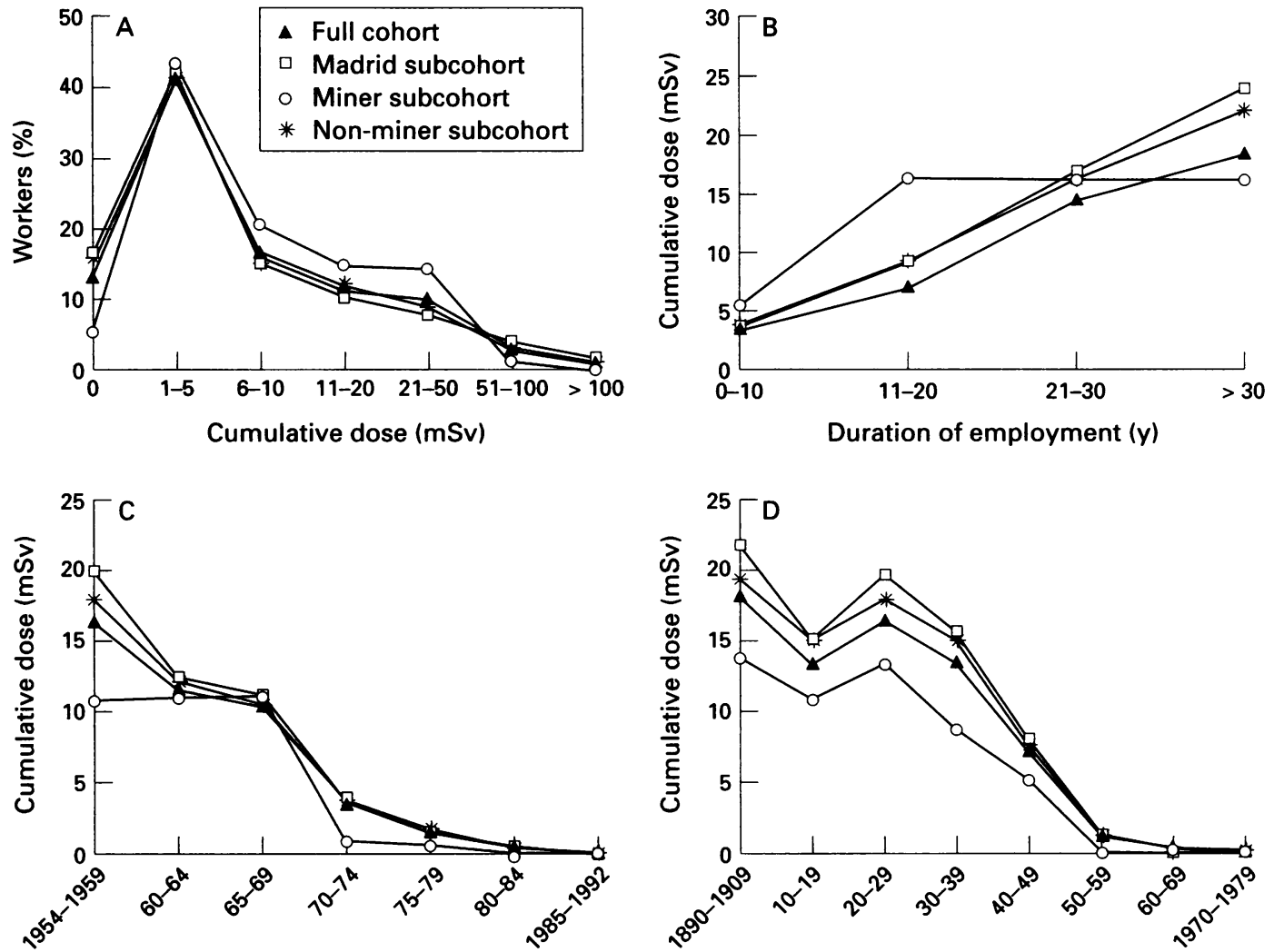

Year of hire at JEN

No substantial modification was found in these results when five and 10 year latency periods were taken into account, or when SMRs were computed solely for workers with dosimetric records. Similarly, we found no substantial change in SMR values by dose or any dose-response relation.

Across the three subcohorts, SMRs for the leading causes of death were largely similar (table 3). The most striking feature was that the SMR for non-malignant respiratory diseases and for external causes of death were particularly low in the Madrid and non-miner subcohorts. Furthermore, the high SMR for respiratory diseases found in the full cohort was ascribable to the high and significant excess mortality due to this same cause in the miner subcohort (SMR 2.94; 95\% CI 2.27 to 3.75). This finding likewise accounts for the SMR for all causes of death attaining a value of $1.10(95 \%$ CI 0.98 to 1.24$)$ in the miner subgroup.

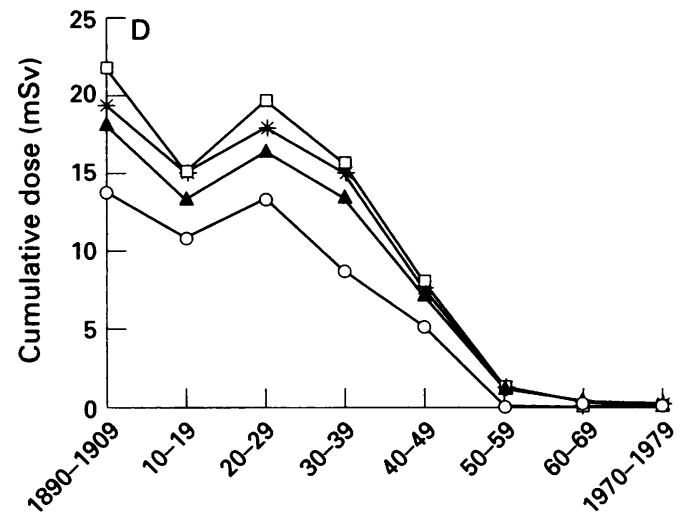

Year of birth

Table 4 shows SMRs for the principal tumour sites. For the cohort as a whole, bone tumours alone registered significantly increased mortality (SMR 2.95; 95\% CI 1.08 to $6 \cdot 43)$. Also, cancer of the lower respiratory tract recorded a value close to one. Most of the other tumour sites registered few events, thereby rendering their SMRs imprecise. In the subcohorts, significance was not reached for any of the tumour sites, yet mortality due to bone cancer was increased for all three (table 4). Furthermore, in the miner subcohort the increased mortality from lung cancer bordered on significance (SMR 1.50; $95 \%$ CI 0.96 to $2.23 ; \mathrm{P}=0.055)$.

INTERNAL COMPARISON OF MORTALITY AMONG THE JEN POPULATION BY LEVEL OF IONISING RADIATION

Table 5 shows information that suggests that exposure to ionising radiation received by JEN workers had no influence on mortality from

Table 3 SMRs for the principal causes of death, 1954-92

\begin{tabular}{|c|c|c|c|c|c|c|c|c|}
\hline \multirow[b]{2}{*}{$\begin{array}{l}\text { Causes of } \\
\text { death (ICD-9) }\end{array}$} & \multicolumn{2}{|l|}{ Cohort } & \multicolumn{2}{|c|}{ Madrid subcohort } & \multicolumn{2}{|c|}{ Miner subcohort } & \multicolumn{2}{|c|}{ Non-miner subcohort } \\
\hline & $\begin{array}{l}\text { Deaths } \\
\text { observed }\end{array}$ & $S M R^{\star}(95 \% C I)$ & $\begin{array}{l}\text { Deaths } \\
\text { observed }\end{array}$ & $S M R^{*}(95 \% C I)$ & $\begin{array}{l}\text { Deaths } \\
\text { observed }\end{array}$ & $S M R^{*}(95 \% C I)$ & $\begin{array}{l}\text { Deaths } \\
\text { observed }\end{array}$ & $S M R^{\star}(95 \% C I)$ \\
\hline All causes & 591 & $0.80(0.74$ to 0.87$)$ & 192 & $0.60(0.52$ to 0.69$)$ & 273 & $1 \cdot 10(0.98$ to $1 \cdot 24)$ & 318 & $0.65(0.58$ to 0.72$)$ \\
\hline $\begin{array}{l}\text { All inectious and paraside } \\
\text { All } 139)\end{array}$ & 11 & $0.50(0.25$ to 0.90$)$ & 1 & $0.11(0.00$ to 0.63$)$ & 9 & $1 \cdot 11(0.50$ to $2 \cdot 10)$ & 2 & $0.15(0.02$ to 0.52$)$ \\
\hline $\begin{array}{l}(140-208) \\
\text { All neurological }(320-389) \\
\text { All circulatory }(390-459)\end{array}$ & $\begin{array}{r}164 \\
8 \\
125\end{array}$ & $\begin{array}{l}0.83(0.71 \text { to } 0.97) \\
0.88(0.38 \text { to } 1.74) \\
0.49(0.41 \text { to } 0.57)\end{array}$ & $\begin{array}{r}68 \\
2 \\
51\end{array}$ & $\begin{array}{l}0.77(0.60 \text { to } 0.98) \\
0.49(0.06 \text { to } 1.77) \\
0.48(0.36 \text { to } 0.63)\end{array}$ & $\begin{array}{r}63 \\
4 \\
48\end{array}$ & $\begin{array}{l}0.97(0.75 \text { to } 1.24) \\
1.36(0.37 \text { to } 3.49) \\
0.55(0.41 \text { to } 0.73)\end{array}$ & $\begin{array}{r}101 \\
4 \\
77\end{array}$ & $\begin{array}{l}0.77(0.62 \text { to } 0.93) \\
0.65(0.18 \text { to } 1.67) \\
0.46(0.36 \text { to } 0.57)\end{array}$ \\
\hline $\begin{array}{l}\text { All non-malignant respiratory } \\
(460-519) \\
\text { All digestive (520-579) } \\
\text { External causes (E800-E999) }\end{array}$ & $\begin{array}{l}82 \\
41 \\
48\end{array}$ & $\begin{array}{l}1.31(1.04 \text { to } 1.63) \\
0.66(0.47 \text { to } 0.89) \\
0.72(0.53 \text { to } 0.95)\end{array}$ & $\begin{array}{r}6 \\
16 \\
19\end{array}$ & $\begin{array}{l}0.24(0.09 \text { to } 0.52) \\
0.59(0.34 \text { to } 0.95) \\
0.58(0.35 \text { to } 0.91)\end{array}$ & $\begin{array}{l}65 \\
14 \\
19\end{array}$ & $\begin{array}{l}2.94(2.27 \text { to } 3.75) \\
0.66(0.36 \text { to } 1.10) \\
0.94(0.57 \text { to } 1.47)\end{array}$ & $\begin{array}{l}17 \\
27 \\
29\end{array}$ & $\begin{array}{l}0.42(0.25 \text { to } 0.68) \\
0.65(0.43 \text { to } 0.95) \\
0.62(0.42 \text { to } 0.89)\end{array}$ \\
\hline
\end{tabular}

*Based on national mortalities for the same age, sex, and calendar period. 
Table 4 SMRs for the principal tumour sites, 1954-92

\begin{tabular}{|c|c|c|c|c|c|c|c|c|}
\hline \multirow[b]{2}{*}{$\begin{array}{l}\text { Causes of } \\
\text { death (ICD-9) }\end{array}$} & \multicolumn{2}{|l|}{ Cohort } & \multicolumn{2}{|c|}{ Madrid subcohort } & \multicolumn{2}{|c|}{ Miner subcohort } & \multicolumn{2}{|c|}{ Non-miner subcohort } \\
\hline & $\begin{array}{l}\text { Deaths } \\
\text { observed }\end{array}$ & $S M R^{*}(95 \% C I)$ & $\begin{array}{l}\text { Deaths } \\
\text { observed }\end{array}$ & $S M R^{\star}(95 \% C I)$ & $\begin{array}{l}\text { Deaths } \\
\text { observed }\end{array}$ & $S M R^{\star}(95 \% C I)$ & $\begin{array}{l}\text { Deaths } \\
\text { observed }\end{array}$ & $S M R^{\star}(95 \% C I)$ \\
\hline \multicolumn{9}{|l|}{ All malignant } \\
\hline $\begin{array}{c}\text { tumours }(140-208) \\
\text { Oral }(140-149)\end{array}$ & $\begin{array}{r}164 \\
7\end{array}$ & $\begin{array}{l}0.83(0.71 \text { to } 0.97) \\
0.98(0.39 \text { to } 2.01)\end{array}$ & $\begin{array}{r}68 \\
5\end{array}$ & $\begin{array}{l}0.77(0.60 \text { to } 0.98) \\
1.52(0.49 \text { to } 3.56)\end{array}$ & $\begin{array}{r}63 \\
2\end{array}$ & $\begin{array}{l}0.97(0.75 \text { to } 1.24) \\
0.87(0.10 \text { to } 3.13)\end{array}$ & $\begin{array}{r}101 \\
5\end{array}$ & $\begin{array}{l}0.77(0.62 \text { to } 0.93) \\
1.03(0.33 \text { to } 2.40)\end{array}$ \\
\hline Stomach (151) & 19 & $0.81(0.49$ to 1.26$)$ & 11 & $1.12(0.56$ to 2.01$)$ & 7 & $0.85(0.34$ to 1.75$)$ & 12 & $0.79(0.41$ to 1.38$)$ \\
\hline Colon (153) & 7 & $0.83(0.33$ to 1.72$)$ & 3 & $0.79(0.16$ to 2.31$)$ & 1 & $0.37(0.00$ to 2.06$)$ & 6 & $1.05(0.39$ to 2.30$)$ \\
\hline \multicolumn{9}{|l|}{ Liver and biliary tract } \\
\hline $\begin{array}{l}(155-156) \\
\text { Lung }(162-163)\end{array}$ & $\begin{array}{l}10 \\
45\end{array}$ & $\begin{array}{l}1.51(0.86 \text { to } 2.46) \\
0.98(0.71 \text { to } 1.31)\end{array}$ & 11 & $\begin{array}{l}1.31(0.60 \text { to } 3.11) \\
0.55(0.28 \text { to } 0.99)\end{array}$ & $\begin{array}{r}4 \\
24\end{array}$ & $\begin{array}{l}1.13(0.30 \text { to } 2.89) \\
1.50(0.96 \text { to } 2.23)\end{array}$ & $\begin{array}{l}12 \\
21\end{array}$ & $0.70(0.43$ to 1.07$)$ \\
\hline Bone $(170)$ & 6 & $2.95(1.08$ to 6.43$)$ & 3 & $3.36(0.67$ to 9.81$)$ & 3 & $4.39(0.88$ to 12.84$)$ & 3 & $2.22(0.45$ to 6.50$)$ \\
\hline Prostate $(185)$ & 7 & $0.73(0.29$ to 1.51$)$ & 5 & $1.35(0.44$ to 3.15$)$ & 1 & $0.28(0.00$ to 1.54$)$ & 6 & $1.01(0.37$ to 2.21$)$ \\
\hline Kidney (189) & 4 & $1.26(0.34$ to 3.21$)$ & 1 & $0.71(0.01$ to 3.93$)$ & 2 & $1.87(0.21$ to 6.76$)$ & 2 & $0.94(0.11$ to 3.41$)$ \\
\hline Nervous system (191-192) & 9 & $1.33(0.61$ to 2.52$)$ & 5 & $1.59(0.51$ to 3.71$)$ & 2 & $0.92(0.10$ to 3.31$)$ & 7 & $1.52(0.61$ to 3.13$)$ \\
\hline Hodgkin's disease (201) & 2 & $1.26(0.41$ to 4.53$)$ & 1 & $1.33(0.02$ to 7.42$)$ & 0 & $0.00(0.00$ to 7.29$)$ & 2 & $1.83(0.21$ to 6.62$)$ \\
\hline \multicolumn{9}{|l|}{ Myeloma and other } \\
\hline$(202-203)$ & 3 & $0.92(0.19$ to 2.70$)$ & 2 & $1.28(0.14$ to 4.63$)$ & 1 & $1.00(0.01$ to 5.59$)$ & 2 & $0.89(0.10$ to 3.21$)$ \\
\hline Leukaemias (204-208) & 4 & $0.70(0.19$ to 1.80$)$ & 2 & $0.73(0.08$ to 2.63$)$ & 0 & $0.00(0.00$ to 2.12$)$ & 4 & $1.01(0.27$ to 2.59$)$ \\
\hline
\end{tabular}

${ }^{\star}$ Based on national mortalities for the same age, sex, and calendar period.

Table 5 Mortality from lung cancer by cumulative dose of ionising radiation (dose quartiles)

\begin{tabular}{|c|c|c|c|c|c|c|c|c|}
\hline & \multicolumn{2}{|l|}{ Cohort } & \multicolumn{2}{|l|}{ Madrid subcohort } & \multicolumn{2}{|l|}{ Miner subcohort } & \multicolumn{2}{|l|}{ Non-miner subcohort } \\
\hline & $R R(95 \% C I)$ & Pvalue & $R R(95 \% C I)$ & Pvalue & $R R(95 \% C I)$ & Pvalue & $R R(95 \% C I)$ & Pvalue \\
\hline Quartile 1 & 1.00 & - & $1 \cdot 00$ & - & $1 \cdot 00$ & - & 1.00 & $\ldots$ \\
\hline Quartile 2 & $1.00(0.39$ to 2.57$)$ & 0.99 & $0.80(0.11$ to 5.89$)$ & 0.83 & $1.34(0.42$ to $4 \cdot 24)$ & 0.62 & $0.83(0.16$ to 4.30$)$ & $0 \cdot 83$ \\
\hline Quartile 3 & $1.60(0.78$ to 3.29$)$ & $0 \cdot 20$ & $1.16(0.21$ to 6.55$)$ & $0 \cdot 87$ & $1.61(0.55$ to 4.73$)$ & 0.38 & $2.37(0.78$ to 7.21$)$ & 0.13 \\
\hline Quartile 4 & $0.94(0.41$ to 2.15$)$ & 0.88 & $0.51(0.01$ to 3.94$)$ & 0.52 & $1.02(0.32$ to 3.23$)$ & 0.97 & $1.32(0.37$ to 4.68$)$ & 0.67 \\
\hline Tobacco & $2.40(0.98$ to 5.83$)$ & 0.05 & $1.49(0.33$ to 6.67$)$ & 0.60 & $3.94(0.85$ to 18.26$)$ & 0.08 & $1.49(0.47$ to 4.71$)$ & 0.49 \\
\hline
\end{tabular}

$\mathrm{RR}=$ Mortality rates ratio, adjusted by age, calendar time, and tobacco consumption, obtained by Poisson modelling.

Quartile $1 \geqslant 0$ and $<0.9 \mathrm{mSv}$; Quartile $2 \geqslant 0.9$ and $<4.035 \mathrm{mSv}$; Quartile $3 \geqslant 4.035 \mathrm{mSv}$ and $<11.5 \mathrm{mSv}$; Quartile $4 \geqslant 11.5 \mathrm{mSv}$.

lung cancer. We found no instance of significantly increased mortality by dose nor any dose-response relation between ionising radiation and mortality in the cohort. As was to be expected, smoking was associated with significantly increased mortality from lung cancer.

These results held when data were reanalysed with a five and 10 year latency. Although the findings in the three subcohorts were in line with those for the full cohort, the smaller numbers involved rendered the effect estimators more unstable and imprecise.

\section{Discussion}

Compared with the Spanish population overall, the JEN cohort showed significantly increased mortality due to non-malignant respiratory diseases and bone tumours. However, significantly increased mortality for any of the causes typically associated with exposure to ionising radiation was not found, whether for the full cohort or for subgroups broken down by work at the Madrid facilities, activity in mining operations, or five and 10 year latency periods.

When mortality of the JEN cohort was studied by level of exposure to ionising radiation, no evidence was found of significantly increased mortality or any dose-response relation for deaths from lung cancer, findings which likewise applied to the subcohorts and different latency periods of five and 10 years.

Most results for our cohort agree with those of previously published studies, ${ }^{417}{ }^{20}$ are compatible with current knowledge in this field, ${ }^{1-32122}$ and to a certain extent stem from methodological limitations imposed by the topic of study..$^{23}$ Most epidemiological studies on workers in the nuclear industry have failed to show evidence of excess mortality compared with the reference population - that is, normally the country as a whole or region in which the industry is located. Such findings are compatible with the healthy worker effect, a phenomenon whereby the mortality found among workers is traditionally lower than that of the populations to which they are compared in epidemiological studies. ${ }^{26}{ }^{27}$ This effect is probably due, among other reasons, to selection of applicants on the grounds of good health at the time of hiring, their permanence in active employment while healthy, and the higher socioeconomic level of people actively employed than those who are not. ${ }^{28}{ }^{29}$

Occasionally, studies on workers in the nuclear industry have shown increased mortality in certain isolated areas, such as leukaemia, ${ }^{4030}$ myeloma, ${ }^{3132}$ tumour of the prostate ${ }^{33}{ }^{34}$, tumour of the thyroid, ${ }^{35}$ lung can$\mathrm{cer}^{36}$ and other site specific cancers. However, these findings have proved difficult to interpret as: they are not consistent across the publications; they may be chance findings thrown up by multiple tests of significance; and they may owe their increased magnitude to small sample sizes which generate unstable effect estimators. ${ }^{24} 25$

The results of our study on the non-miner and Madrid worker subcohorts agreed with those already summarised. Part of the healthy worker effect found (table 3), in line with other publications, was less pronounced in tumours than in overall mortality, and may have been attributable to follow up losses. A scan of the Social Security database, followed 
by a search of the Vital Statistics Office mortality registries is standard procedure for follow up of work cohorts in developed countries. ${ }^{737}$ Yet it was only after 1987 that vital statistics for the Spanish population became accessible on line, with the result that, among subjects not registered on the INE mortality database, it is simply not possible to distinguish the living from those who should be regarded as lost to follow up before 1987 . This circumstance, plus being denied access to vital status data of individual workers in the cohort (for reasons of confidentiality), barred us from gathering information on follow up of the percentage loss in the cohort.

The single item of note was the significantly increased mortality due to bone tumours. This finding has a certain degree of historical plausibility, in that it was found in the early part of the century among workers who painted luminous dials with radium. ${ }^{38}$ It must be said, however, that it was based on only six deaths in the full cohort and three deaths in the non-miner cohort. Then again, this tumour is especially associated with exposure to $\alpha$ radiations, a type not predominant among the non-miners in our cohort. Consequently, this finding is beset by the same problems of interpretation as those already described, and follow up of the cohort must therefore be continued, so that its permanence over time can be monitored and uncertainty surrounding its very existence, reduced.

In cases where the mortality of workers in the nuclear industry has been analysed by levels of exposure within the cohort, most studies have failed to show a clear association between dose and cancer mortality. ${ }^{40}$ Effect estimators have likewise proved to be imprecise, being compatible not only with the presence but also with the absence of risk related to exposure. In many instances, this has been due to the low levels of exposure, and the short mean periods of follow up, barely exceeding the latency periods in the potential effects of ionising radiation. It may also be due to non-differential errors in classification of exposure and imprecise measurement of exposure to ionising radiation, resulting from limitations of the measuring instruments and their technical improvement over the course of follow up. These facts possibly also help to explain the results of our study. Thus, exposure registered in the non-miner and Madrid worker subcohorts was about $1 \mathrm{mSv}$ a year. To show that excess mortality is linked to exposure would require a cohort of $10^{5}-10^{6}$ workers. ${ }^{23} 24$

It is of interest that subjects with radiation doses in quartile 3 registered the lowest relative risk (table 5). This result remained unchanged when, with the aim of stabilising mortality in the reference category, subjects with doses in quartile 1 and quartile 2 were grouped together in a single category. The absence of an unequivocal dose-response relation in our data indicated that estimators of excess risk should not be calculated per $\mathrm{mSv} / 10^{6}$, as is often seen in publications dealing with assessment of risk for ionising radiation. This somewhat unexpected finding may be due to the relative instability of the effect estimators, which were based on few deaths, as can be seen from their wide $95 \%$ CIs. Another explanation might lie in selection bias, whereby staff with the soundest health would have been hired for jobs that were the most hazardous, and so most exposed to radiation. It might equally be the consequence of the action of a residual confounder (a risk factor for mortality inversely proportional to dose), uncontrolled because of lack of information.

In contrast to the absence of a clear effect and the variability of the results of studies carried out on workers in the nuclear industry, studies on miners of uranium and other minerals that emit radon and related radioactive byproducts have proved to be consistent in suggesting a rise in mortality from lung cancer in these workers. ${ }^{19} 39$ Radon shows a positive dose-response relation with lung cancer, both in smokers and non-smokers. Also, it interacts with tobacco to produce lung cancer. ${ }^{40-42}$ On the other hand, the effects of radon seem to be restricted to the production of bronchopulmonary tumours.

Increased total mortality, bordering on significance, was found in the miner subcohort compared with the Spanish population overall. This increase resulted from an appreciable rise in mortality due to non-malignant respiratory diseases, and to an almost significant increase in mortality from lung cancer. Nevertheless, we failed to find a relation between dose and mortality from lung cancer in the subcohort. This could be attributable to several facts: firstly, the relative youth of the miner subcohort, which for the most part had not yet reached the ages of highest risk of lung cancer; secondly, the moderate doses of exposure received by these workers (table 2), because they had worked outside, in open pit mines in many instances, and had rigorously complied with the regulations for protection against ionising radiation; and thirdly, the absence of internal dosimetry and environmental exposure readings might have hindered identification of the relation. In fact, external dose probably represents only a small part of the doses to the lung among miners. Added to these considerations is the small size of the miner subcohort, which had only 24 cases of lung cancer (table 4).

We express our gratitude to the following: Dr Salvador de Mateo, for his help in designing software programs during the Mateo, for his help in designing software programs during the Olmo, and $\mathrm{M}^{2}$ Ageles García López for providing technical support for this research; Drs Antonio Rebollar, Rafael Mingot, support for this research; Drs Antonio Rebollar, Rafael Mingot,
Rafael Sáenz Gancedo, José Ramón Banegas, and Fernando
García Benavides for critical comments to the manuscript; Mr Garcia Benavides for critical comments to the manuscript; $\mathrm{Mr}$ Michael D Benedict for preparing the English language ver-
sion; the National Centre for Epidemiology at the Instituto de Salud Carlos III, for providing us with the computerised 1954-92 national mortality data used in this study; and lastly the Directorate General for Demographic and Social Statistics of the Instituto Nacional de Estadística, for providing information on death and causes of death of the study cohort. This work has been partially funded by European Union Contract BI 6-0229-E.

1 National Research Council Committee on the Biological Effects of Ionizing Radiation. Health risks of radon and other internally deposited alpha-emitters (BEIR IV) Washington DC: National Academy Press, 1988.

2 National Research Council Committee on the Biological Effects of Ionizing Radiation. Health effects of exposure to 
low levels of ionizing radiations (BEIR V). Washington, DC: National Academy Press, 1990.

3 United Nations Scientific Committee on the Effects of Atomic Radiation (UNSCEAR). Sources, effects and risks of ionizing radiation. New York: United Nations, 1988. ((Report E88.IX.7.)

4 International Agency for Research on Cancer. IARC Study Group on Cancer Risks among Nuclear Industry Workers. Direct estimates of cancer mortality due to low doses of ionizing radiation: an international study. Lancet 1994;344:1039-43.

5 Ambach W. Occupational low-dose exposure to ionizing radiation. Lancet 1994;344:1037-8.

6 Organización Panamericana de la Salud. Manual de la Clasificación Estadistica Internacional de Enfermedades, Traumatismos y Causas de Defunción, 9u Revision. Traumatismos y Causas de Defuncion, 9 Revision.
Washington, DC: Pan American Health Organisation, Washingt 1978 .

7 Checkoway H, Pearce N, Crawford-Brown DJ. Cohort studies. In: Checkoway H, Pearce N, Crawford-Brown DJ. Research methods in occupational epidemiology. New York: Oxford University Press, 1989:103-69.

8 Pearce N, Checkoway H. A simple computer program for generating person-time data in cohort studies involving time related factors. Am $\mathcal{F}$ Epidemiol 1987;125:1085-91.

9 Breslow NE, Day NE. Rates and rate standardization. In Breslow NE, Day NE. Statistical methods in cancer research. Vol ii: the analysis of cohort studies. Lyon: International Agency for Research on Cancer, 1987:48-81

10 Liddell FD. Simple exact analysis of the standardized mortality ratio. $\mathcal{F}$ Epidemiol Community Health 1984;38:85-8.

11 Frome EL, Checkoway $H$. Use of regression models in estimating incidence rates and ratios. Am 7 Epidemiol 1985; mating inciden

12 Checkoway H, Pearce N, Crawford-Brown DJ. Advanced statistical analysis. In: Checkoway $\mathrm{H}$, Pearce $\mathrm{N}$, Crawford-Brown DJ, eds. Research methods in occupational epidemiology. New York: Oxford University Press, 1989:232-63.

13 Breslow NE, Day NE. Fitting models to grouped data. In: Breslow NE, Day NE. Statistical methods in cancer research. Vol ii: the analysis of cohort studies. Lyon: International Agency for Research on Cancer, 1987:120-77.

14 SAS Institute. SAS/STAT users guide, release 6.03 edition. Cary, NC: SAS Institute, 1988.

15 Statistics and Epidemiology Research Corporation. Egret. Reference manual. Seattle: SERC, 1990.

16 Government Gazette (Boletin Oficial del Estado-BOE) Royal Decree (Real Decreto) 53/92, 24 fanuary 1992, approving regulations governing health protection against ionizing radiation. Madrid: BOE, 12 February 1992. (BOE No 37.)

17 Darby SC, Doll R. Occupational epidemiology. Problems in reaching an overview. Minutes of the Proceedings of British Nuclear Society. London: BNS, 1987

18 Gilbert ES, Cragle DL, Wiggs LD. Updated analyses of combined mortality data for workers at the Hanford site, Oak Ridge National Laboratory, and Rocky Flats Weapons Plant. Radiat Res 1993;136:408-21.

19 Axelson O. Occupational and environmental exposures to radon: cancer risks. Annu Rev Public Health 1991;12: 235-55.

20 Upton AC, Shore RE, Harley NH. The health effects of low-level ionizing radiation. Annu Rev Public Health 1992;12:127-50

21 International Commission on Radiological Protection. Recommendations of the International Commission on Radiological Protection. Oxford: Pergamon, 1991. (ICRP 60.)
22 Hendee WR. Estimation of radiation risks. BEIR V and its significance for medicine. $\mathscr{F} A M A$ 1992;268 $620-4$

23 Land C. Estimating cancer risks from low doses of ionizing radiation. Science 1980;209:1197-203.

24 Shore RE. Occupational radiation studies: status, problems, and prospects. Health Phys 1990;59:63-8.

25 Acquavella JF, Friedlander BR, Ireland BK. Interpretation of low to moderate relative risks in environmental epidemiologic studies. Annu Rev Public Health 1994;15 179-201.

26 McMichael AJ, Spirtas R, Kupper LL. An epidemiologic study of mortality within a cohort of rubber workers 1964-72. F Occup Med 1974;16:458-64.

27 McMichael AJ. Standardized mortality ratio and the "healthy worker effect": scratching beneath the surface. $\mathcal{F}$ Occup Med 1976;18:165-8.

28 Wen CP, Tsai SP, Gibson RL. Anatomy of the healthy worker effect. A critical review. F Occup Med 1983; 25:283-9.

29 Carpenter LM. Some observations on the healthy worke effect. Br F Ind Med 1987;44:289-91.

30 Wing S, Shy CM, Wood JL, Wolf S, Cragle DL, Frome EL. Mortality among workers at Oak Ridge National Laboratory. Evidence of radiation effects in follow-up through 1984. FAMA 1991;265:1397-402.

31 Cuzick J. Radiation induced myelomatosis. $N$ Engl f Med 1981;304:204-10.

32 Gilbert ES, Omohundro E, Buchanan JA, Holter NA. Mortality of workers at the Hanford site: $1945-86$ Mealth Phys 1993:64:577-90.
Hertality of workers at the

33 Fraser P, Carpenter L, Maconochie N, Higgins C, Booth $M$, Beral V. Cancer mortality and morbidity in employees of the United Kingdom Atomic Energy Authority, 1946-86. Br f Cancer 1993;67:615-24.

34 Beral V, Fraser P, Carpenter L, Booth M, Brown A, Rose G Mortality of the employees of the Atomic Weapon Establishment, 1951-82. BMF 1988;297;757-70.

35 Douglas AJ, Omar RZ, Smith PG. Cancer mortality and morbidity among workers at the Sellafield plant of British Nuclear Fuels. Br 7 Cancer 1994;70:1232-43.

36 Loomis DP, Wolf SH. Mortality of workers at a nuclear materials production plant at Oak Ridge, Tennessee, 1947-90. Am F Ind Med 1996;29:131-41.

37 Rodríguez Artalejo F, Banegas JR, Martin Pérez J, Rey Calero J. Diseño de un sistema de recogida de datos prospectivo sobre la salud de los trabajadores del CIEMAT. Madrid: sobre la salud de los trabajadores del CIEMAT. Madrid: Universidad Autónoma de Madrid, 1992

38 Martland HS. The occurrence of malignancy in radioactive persons. A general review of data gathered in the study of radium painters, with special reference to the occurrence of osteogenic sarcoma and the interrelationship of certain blood diseases. Am $\mathcal{F}$ Cancer 1931;15 2435-516.

39 International Commission on Radiological Protection Protection against radon-222 at home and at work. Oxford: Pergamon, 1993. (ICRP 65.)

40 Hornung RW, Meinhardt TH. Quantitative risk assessment of lung cancer in US uranium miners. Health Phys 1987;52:417-30.

41 Samet JM, Pathak DR, Morgan MV, Key CR, Valdivi $\mathrm{AA}$, Lubin JH. Lung cancer mortality and exposure to AA, Lubin JH. Lung cancer mortality and exposure to radon progeny in a cohort of New Mexico und

42 Moolgavkar SH, Luebeck EG, Krewski D, Zielinski JM Radon, cigarette smoke, and lung cancer: a re-analysis of the Colorado plateau uranium miners' data. Epidemiolog 1993;4:204-17. 